Retraction

\title{
Retracted: Experimental Study of Local Inner Ear Gene Therapy for Controlling Autoimmune Sensorineural Hearing Loss
}

\author{
BioMed Research International \\ Received 1 March 2017; Accepted 1 March 2017; Published 13 July 2017 \\ Copyright (C) 2017 BioMed Research International. This is an open access article distributed under the Creative Commons \\ Attribution License, which permits unrestricted use, distribution, and reproduction in any medium, provided the original work is \\ properly cited.
}

BioMed Research International has retracted the article titled "Experimental Study of Local Inner Ear Gene Therapy for Controlling Autoimmune Sensorineural Hearing Loss" [1]. Figures 1(a) and 1(b) show identical gels other than the part of the right-hand lane that includes the band of interest in Figure 1(b).

\section{References}

[1] C.-Q. Tan, X. Gao, W.-J. Cai, X.-Y. Qian, L. Lu, and H. Huang, "Experimental study of local inner ear gene therapy for controlling autoimmune sensorineural hearing loss," BioMed Research International, vol. 2014, Article ID 134658, 10 pages, 2014. 